\title{
Profil saliva pada penyirih di Kecamatan Rembon Kabupaten Tana Toraja Salivary profile of betel quid tobacco chewers in District of Rembon, Tana Toraja
}

\author{
${ }^{1}$ Marcelina, ${ }^{2}$ Rasmidar Samad \\ ${ }^{1}$ Mahasiswa tahap profesi \\ ${ }^{2}$ Bagian Ilmu Kesehatan Gigi Masyarakat \\ Fakultas Kedokteran Gigi Universitas Hasanuddin \\ Makassar, Indonesia
}

\begin{abstract}
Betel quid tobacco (BQT) chewing is a process of chewing betel leaves, areca nut, lime, gambier, and tobacco. Chewing and chemical stimulation of BQT can affect the salivary profile. The purpose of this study is to observe the differences of salivary profile such as volume, $\mathrm{pH}$, and salivary inorganic component $\left(\mathrm{Na}^{+}, \mathrm{K}^{+}, \mathrm{Ca}^{2+}, \mathrm{Mg}^{2+}\right.$ and phosphate) between BQT chewers and non-chewers. This study is an observation analytic with cross sectional design on 30-60 years old women that live in Rembon district of Tana Toraja ( $n=96)$ using cluster random sampling technique. Salivary volume was measured by measured glass, salivary $p H$ was measured by indicator pH (Macherey-Nagel). The content of the salivary inorganic component was seen using atomic absorption spectrophotometer in BPTP Laboratory, Maros. Data were analyzed by t-test and chi square test using SPSS v 15.0. The result were mean of salivary volume (chewers $=3.88 \mathrm{ml} / 10 \mathrm{~s} ; \mathrm{p}=0.051)$. Mean of salivary $\mathrm{pH}$ (chewers=6.92; $p=0.001)$. Mean of salivary $\mathrm{Na}^{+}$(chewers=0.38 ppm; $\left.\mathrm{p}=0.112\right), \mathrm{Mg}^{2+}$ (chewers $\left.=11.9 \mathrm{ppm} ; \mathrm{p}=0.002\right)$, phosphate (chewers $=156.8 \mathrm{ppm} ; \mathrm{p}=0.001), \mathrm{Ca}^{2+}$ (chewers $\left.=174.8 \mathrm{ppm} ; \mathrm{p}=0.000\right), \mathrm{K}^{+}($chewers $=445.9 \mathrm{ppm} ; \mathrm{p}=0.429)$. It was concluded that there was no significant difference on salivary volume, $\mathrm{pH}, \mathrm{Na}^{+}$and $\mathrm{K}^{+}$content between chewers and non chewers, but the content of salivary $\mathrm{Mg}^{2+}, \mathrm{Ca}^{2+}$ and phosphate had significant difference.
\end{abstract}

Keywords: BTQ chewing, saliva, volume, $p H$, inorganic component

\begin{abstract}
ABSTRAK
Menyirih merupakan suatu proses mengunyah sirih, pinang, kapur sirih, gambir dan tembakau kering. Proses pengunyahan dan rangsangan kimiawi dari bahan-bahan yang digunakan pada proses menyirih dapat mempengaruhi profil saliva. Tujuan penelitian ini adalah untuk megetahui perbedaan profil saliva yaitu volume, $\mathrm{pH}$ dan komponen anorganik saliva $\left(\mathrm{Na}^{+}, \mathrm{K}^{+}, \mathrm{Ca}^{2+}, \mathrm{Mg}^{2+}\right.$ dan fosfat) penyirih dengan yang tidak menyirih. Penelitian observasi analitik dengan desain cross sectional dilakukan pada wanita di Kecamatan Rembon Tana Toraja yang berusia 30-60 tahun $(\mathrm{n}=96)$, dengan teknik cluster random sampling. Volume saliva diukur dengan menggunakan tabung ukur, $\mathrm{pH}$ saliva dinilai menggunakan indikator $\mathrm{pH}$ (Macherey-Nagel). Kandungan komponen anorganik saliva diuji menggunakan alat spektrofotometer serapan atom yang dilakukan di Laboratorium BPTP Maros. Data dianalisis dengan uji-t dan chisquare $(\mathrm{p}=0,05)$ menggunakan program SPSS versi 15,0 . Hasil penelitian menunjukkan rerata volume saliva penyirih=3,88 ml/10 menit $(\mathrm{p}=0,051)$. Rerata $\mathrm{pH}$ penyirih=6,92 $(\mathrm{p}=0,001)$. Rerata kandungan $\mathrm{Na}^{+}$penyirih $=0,38 \mathrm{ppm}$ $(\mathrm{p}=0,112), \mathrm{Mg}^{2+}$ penyirih=11,9 ppm $(\mathrm{p}=0,002)$, fosfat penyirih=156,8 $\mathrm{ppm}(\mathrm{p}=0,001), \mathrm{Ca}^{2+}$ penyirih=174,8 $\mathrm{ppm}$ $(\mathrm{p}=0,000), \mathrm{K}^{+}$penyirih=445,9 ppm $(\mathrm{p}=0,429)$. Disimpulkan bahwa volume, $\mathrm{pH}$, kandungan komponen $\mathrm{Na}^{+}$dan $\mathrm{K}^{+}$ saliva penyirih tidak memiliki perbedaan yang signifikan dengan yang tidak menyirih, sedangkan kandungan komponen $\mathrm{Mg}^{2+}, \mathrm{Ca}^{2+}$ dan fosfat memiliki perbedaan yang signifikan.
\end{abstract}

Kata kunci: menyirih, saliva, volume, $\mathrm{pH}$, komponen anorganik

Koresponden: Marcelina,E-mail:jcluv_marce_chan@hotmail.com

\section{PENDAHULUAN}

Bangsa Indonesia terdiri dari berbagai macam suku,danmempunyai kebiasaan yang beranekaragam pula,salah satunya adalah menyirih. ${ }^{1}$ Menyirih adalah proses meramu campuran dari unsur yang terpilih dan dibungkus dalam daun sirih sehingga dihasilkan sugi sirih (quid). Umumnya, bahan yang digunakan untuk menyirih terdiri dari biji buah pinang (Areca catechu),daun sirih (Piper betel) dan kapur (kalsium hidroksi). Di beberapa daerah atau negara,tembakau juga dimasukkan ke dalam quid. ${ }^{1}$

Walaupunjumlah penyirih sudah agak berkurang, kebiasaan ini ternyata masih dilakukan dalam jumlah yang cukup banyak di daerah pedesaan wilayah tertentu. ${ }^{1}$ Suku Toraja adalah suku yang menetap di pegunungan bagian utara Sulawesi Selatan, yang dikenal memiliki kebiasaan menyirih. Di Toraja, pemandangan kaum ibu menyirih atau ma'pangan (dalam bahasa daerah setempat) bukanlah hal asing. Setiap hari kita bisa mendapati ibu-ibu melakukan kegiatan ini,terlebih pada saat ada acara rambu solo (upacara kematian masyarakat Toraja) dan rambu tuka (pesta pernikahan dan ulang tahun). ${ }^{2}$

Saliva adalah suatu cairan kompleks yang terdiri dari atas campuran sekresi dari kelenjar ludah besar dan kecil yang ada pada mukosa oral. ${ }^{3}$ Komposisi 
saliva bervariasi, terdiri dari komponen anorganik dan organik. Saliva $99,5 \%$ berupa cairan dan sisanya merupakan komponen yang larut; dibedakan atas komponen anorganik elektrolit dalam bentuk ion, seperti $\mathrm{Na}^{+}, \mathrm{K}^{+}, \mathrm{Ca}^{2+}, \mathrm{Mg}^{2+}, \mathrm{Cl}^{-}$, ion $\mathrm{OH}^{-}$dan fosfat. Sedangkan komponen organik terutama protein, musin, lipida, asam lemak dan ureum. Saliva juga mengandung fluoryang meningkatkan remineralisasi gigi. Selain itu, di dalam saliva terkandung lisosim, sistem laktoperoksidase-isitiosianat, laktoferin, dan imunoglobulin yang beraktivitas antibakteri. ${ }^{4,5}$

Sekresi saliva dapat dipengaruhi oleh beberapa faktor, antara lain rangsangan mekanis, kimiawi, dan neuronal. ${ }^{6}$ Sekresi saliva dalam sehari berbedabeda pada tiap individu.Sekresi saliva normal berkisar 500-1500 ml/24 jam. ${ }^{7}$ Beberapa penelitian dari laju aliran saliva yang tidak terstimulasi pada individu sehat telah menemukannilai saliva keseluruhan sekitar 0,3-0,5 ml/menit.Sedangkan laju aliran saliva yang terstimulasi dapat mencapai $10 \mathrm{ml} /$ menit. $^{8}$ Adapun nilai normal $\mathrm{pH}$ saliva berkisar antara 6,7-7,3. ${ }^{6}$

Saliva merupakan cairan rongga mulut yang antara lain berfungsi melindungi jaringan dalam rongga mulut dengan pembersihan secara mekanis untuk mengurangi akumulasi plak, lubrikasi elemen gigi-geligi,sistem bufer,antibakteri,pencernaan, dan pembersihan makanan. Fungsi proteksi ini sangat dipengaruhi oleh perubahan yang terkait dengan komposisi maupun viskositas, derajat keasaaman, serta susunanion dan proteinnya.Susunan dan jumlah sekresi saliva bergantung pada aktivitas tubuh serta adanya rangsangan. ${ }^{9}$

Aktivitas pengunyahan merupakan rangsangan mekanis yang dapat meningkatkan produksi saliva seperti mengunyah sirih. ${ }^{10}$ Sugi sirih yang kasar akan memerlukan kekuatan mastikasi yang lebih besar yang juga akan meningkatkan laju aliran saliva. ${ }^{8}$ Begitupun dengan rasa dari bahan yang digunakan untuk menyirih merupakan rangsangan kimiawi yang dapat meningkatkan produksi saliva. Peningkatan laju aliran saliva, mengubah keasaman saliva dengan peningkatan sekresi bikarbonat yang akanmenaikkan $\mathrm{pH}$. Korelasi yang signifikan antara laju aliran dan $\mathrm{pH}$ saliva pada pengunyah sirih memperlihatkan suatu pola peningkatan yang dapat mencerminkan perubahan pada unsur elektrolit saliva pengunyah. Peran kapur sirih dalam menyirih telah menjadi perhatian.Kapur sirih (kalsium oksida dalam bentuk encer kalsium hidroksida) dapat menyebabkan luka radikal bebas atau kadar alkali yang tinggi mungkin bereaksi dengan sistem bufer dan mengubah $\mathrm{pH}^{8}$

Tujuandilakukannya penelitian ini adalah untuk mengetahui perbedaan profil saliva penyirih dengan yang tidak menyirih.

\section{BAHAN DAN METODE}

Rancangan penelitian ini adalah studi cross sectional dengan populasi penelitian adalah wanita usia 30-60 tahun di Kecamatan Rembon Kabupaten Tana Toraja. Subjek tidak sedang mengkonsumsi obat yang dapat mempengaruhi profil saliva, tidak hamil atau haid, dan memiliki kebiasaan menyirih sampai saat penelitian dilakukan. Kriteria ekslusi adalah subjek menolak ikut dalam penelitian, dan menyirih hanya sesekali. Cara pengambilan subjek dilakukan dengan cara cluster random sampling sehingga diperoleh jumlah sebanyak 96 orang.

Komposisi sirih terdiri dari daun sirih, kapur, buah pinang,gambirserta tembakau yang digosokkan pada gigi-geligi setelah menyirih selesai. Menyirih dilakukan minimal $2 \mathrm{kali} / \mathrm{hari}$ secara terus-menerus selama minimal 1 tahun terakhir.Profil saliva adalah volume, $\mathrm{pH}$ dan komponen anorganik saliva $\left(\mathrm{Na}^{+}\right.$, $\mathrm{K}^{+}, \mathrm{Ca}^{2+}, \mathrm{Mg}^{2+}$ dan fosfat).

Saliva yang dikumpulkan adalah unstimulated whole saliva selama 10 menit dalam tabung ukur. Volume saliva berkisar 0,3-0,5 ml/menit atau 3,0-5,0 $\mathrm{ml} / 10$ menit. Pengumpulan saliva dilakukan pada jam 9.00-24.00 untuk menghindari variasi diurnal. ${ }^{8}$

Keasaman saliva diukur dengan menggunakan indikator $\mathrm{pH}$ (Macherey-Nagel). $\mathrm{pH}$ saliva normal berkisar 6,7-7,3. ${ }^{6}$ Kandungan komponen anorganik saliva dilihat melalui hasil uji dengan menggunakan alat spektrofotometer serapan atom yang dilakukan di Laboratorium BPTP Maros.Pemeriksaan volume dan $\mathrm{pH}$ saliva pada semua subjek, sedangkan untuk kandungan komponen anorganiknya saliva diambil 32 secara random, yaitu 16 yang menyirih dan 16 bukan menyirih.

Data penelitian dianalisis dengan uji-t dan chisquare dengan menggunakan program SPSS 15,0.

\section{HASIL}

Dari subjek yang diperiksa, tampak $74 \%$ sampel tidak melakukan kebiasaan menyirih lagi.Jika ditilik dari kelompok usia, hanya kelompok 50-60 tahun yang lebih banyak masih melakukan kebiasaan menyirih, seperti yang terlihat pada tabel 1 .

Tabel 1 Deskriptif jumlah penyirih dan bukan penyirih

\begin{tabular}{cccc}
\hline \multirow{2}{*}{ Usia } & \multicolumn{2}{c}{ Kebiasaan Menyirih } & \multirow{2}{*}{ Jumlah } \\
\cline { 2 - 3 } & Ya & Tidak & \\
\hline \multirow{2}{*}{$30-39$} & 4 & 34 & 38 \\
& $4,2 \%$ & $35,4 \%$ & $39,6 \%$ \\
$40-49$ & 3 & 24 & 27 \\
& $3,1 \%$ & $25,0 \%$ & $28,1 \%$ \\
\multirow{2}{*}{$50-60$} & 18 & 13 & 31 \\
& $18,8 \%$ & $13,5 \%$ & $32,3 \%$ \\
\hline \multirow{2}{*}{ Jumlah } & 25 & 71 & 96 \\
& $26,0 \%$ & $74,0 \%$ & $100,0 \%$ \\
\hline
\end{tabular}


Tidak ada perbedaan yang signifikan volume saliva antara penyirih dengan bukan penyirih pada setiap kelompok usia. Kebiasaan menyirih tidak berhubungan dengan volume saliva pada penyirih (tabel 2 dan 3).

Tidak terdapat perbedaan yang signifikan antara keasaman saliva penyirih dengan yang tidak menyirih, tetapi terdapat hubungan yang signifikan antara menyirih dengan keasaman saliva (tabel 4). Selain itu, terdapat perbedaan yang signifikan antara kandungan komponen $\mathrm{Mg}^{2+}, \mathrm{Ca}^{2+}$ dan fosfat saliva pada penyirih dan yang bukan penyirih. Sedangkan kandungan komponen $\mathrm{Na}^{+}$dan $\mathrm{K}^{+}$ dalam saliva penyirih dengan bukan penyirih, tidak memiliki perbedaan yang signifikan, seperti tampak pada tabel 5 .

Tabel 2 Rerata volume saliva pada penyirih dan yang tidak menyirih

\begin{tabular}{ccccc}
\hline Usia & Kebiasaan Menyirih & N & Rerata \pm Simpang Baku (ml/10 menit) & P \\
\hline $30-39$ & Ya & 4 & $4,63 \pm 1,52$ & 0,852 \\
& Tidak & 34 & $4,51 \pm 1,13$ & 0,086 \\
$40-49$ & Ya & 3 & $3,60 \pm 0.87$ & 0,860 \\
& Tidak & 24 & $4,42 \pm 0,74$ & \\
\hline \multirow{2}{*}{$50-60$} & Ya & 18 & $3,77 \pm 1,10$ & \\
& Tidak & 13 & $3,83 \pm 0,81$ &
\end{tabular}

Uji t, p < 0,05

Tabel 3 Hubungan menyirih dengan volume saliva

\begin{tabular}{cccccc}
\hline \multirow{2}{*}{ Kebiasaan Menyirih } & \multicolumn{3}{c}{ Volume Saliva } & \multirow{2}{*}{ Jumlah } & \multirow{2}{*}{ P } \\
\cline { 2 - 5 } & Lebih dari normal & Normal & Kurang dari normal & & 0,138 \\
Ya & 4 & 17 & 4 & 25 & $26,0 \%$ \\
Tidak & $4,2 \%$ & $17,7 \%$ & $4,2 \%$ & 71 & $74,0 \%$ \\
\hline \multirow{2}{*}{ Jumlah } & 16 & 52 & $3,1 \%$ & 96 \\
& $16,7 \%$ & $54,2 \%$ & 7 & $100,0 \%$ \\
\hline
\end{tabular}

Uji Chi-Square, $\mathrm{p}<0,05$

Tabel 4 Rerata $\mathrm{pH}$ dan hubungan menyirih dengan $\mathrm{pH}$ saliva

\begin{tabular}{|c|c|c|c|c|c|c|c|}
\hline \multirow[b]{2}{*}{$\begin{array}{l}\text { Kebiasaan } \\
\text { Menyirih }\end{array}$} & \multirow[b]{2}{*}{ Rerata } & \multirow[b]{2}{*}{$P$} & \multicolumn{3}{|c|}{$\mathrm{pH}$ Saliva } & \multirow[b]{2}{*}{ Jumlah } & \multirow[b]{2}{*}{$\mathrm{P}$} \\
\hline & & & $\begin{array}{c}\text { Lebih dari } \\
\text { normal }\end{array}$ & Normal & $\begin{array}{c}\text { Kurang dari } \\
\text { normal }\end{array}$ & & \\
\hline \multirow[t]{2}{*}{$\mathrm{Ya}$} & 6,92 & $0,48^{*}$ & 5 & 14 & 6 & 25 & $0,001^{* *}$ \\
\hline & & & $5,2 \%$ & $14,6 \%$ & $6,3 \%$ & $26,0 \%$ & \\
\hline \multirow[t]{2}{*}{ Tidak } & 6,61 & & 0 & 46 & 25 & 71 & \\
\hline & & & $0,0 \%$ & $47,9 \%$ & $26,0 \%$ & $74,0 \%$ & \\
\hline \multirow{2}{*}{ Jumlah } & & & 5 & 60 & 31 & 96 & \\
\hline & & & $5,2 \%$ & $62,5 \%$ & $32,3 \%$ & $100,0 \%$ & \\
\hline
\end{tabular}

${ }^{*}$ Uji-t, p <0,05; ${ }^{* *}$ Uji Chi-Square, $p<0,05$

Tabel 5 Rerata komponen anorganik saliva $\left(\mathrm{Na}^{+}, \mathrm{Mg}^{2+}\right.$, fosfat, $\mathrm{Ca}^{2+}$ dan $\left.\mathrm{K}^{+}\right)$pada penyirih dan bukan penyirih

\begin{tabular}{cccc}
\hline Komponen Anorganik Saliva & Kebiasaan Menyirih & Rerata \pm Simpang Baku $(\mathrm{ppm})$ & $\mathrm{P}$ \\
\hline \multirow{2}{*}{$\mathrm{Na}^{+}$} & Ya & $0,38 \pm 0,21$ & 0,112 \\
& Tidak & $0,26 \pm 0,21$ & 0,002 \\
$\mathrm{Mg}^{2+}$ & Ya & $11,91 \pm 10,39$ & 0,001 \\
& Tidak & $3,12 \pm 1,58$ & 0,000 \\
& Ya & $156,83 \pm 59,34$ & 0,429 \\
& Tidak & Ya & $233,75 \pm 52,39$ \\
\end{tabular}

Uji-t, p $<0,05$ 


\section{PEMBAHASAN}

Tabel 2 memperlihatkan tidak ada perbedaan yang signifikan antara volume saliva penyirih dengan bukan penyirih pada semua kelompok usia. Hal ini tidak sejalan dengan penelitian yang dilakukan oleh Rooban $\mathrm{dkk}^{8}$, aliran saliva penyirih lebih tinggi signifikan dibandingkan dengan yang bukan penyirih. Peningkatan aliran saliva menyebabkan peningkatan volume sekresi saliva. Rooban dkk memperkirakan bahwa hal ini mungkin mengarah pada peningkatan massa kelenjar saliva akibat pengunyahan kronis atau disebabkan oleh paparan kronis dari satu atau seluruh unsur dari sugi sirih. ${ }^{8}$ Sekresi saliva dipengaruhi oleh berbagai faktor yang meningkatkan atau menurunkan sekresi saliva.Jenis makanan yang dikonsumsi setiap hari mempengaruhi sekresi saliva, seperti kebiasaan mengunyah sugi sirih yang kasar akan membutuhkan tekanan mastikasi yang lebih besar yang juga dapat menyebabkan meningkatnya sekresi saliva ${ }^{8,9}$ Penurunan sekresi saliva dipengaruhi oleh berbagai faktor, seperti menurunnya kesehatan umum, faktor kejiwaan seperti gangguan emosional atau depresi, gangguan sistem saraf pusat atau perifer juga dapat mempengaruhi sekresi saliva, gangguan kelenjar saliva misalnya kelainan pada sel asini dan sel duktus kelenjar saliva juga dapat menyebabkan penurunan sekresi saliva. ${ }^{9}$

Pada tabel 3 diperoleh nilai $\mathrm{p}=0,138$ dari hubungan menyirih dengan volume saliva, berarti tidakadahubungan yang signifikan antara kebiasaan menyirih dengan volume saliva tidak terstimulasi. Adanya faktor-faktor lain yang juga berpengaruh terhadap sekresi saliva yang tidak dapat dikendalikan dalam penelitian ini diantaranya kondisi kejiwaan dan stres. Pada saat stres, sekresi saliva mengalami hambatan. ${ }^{6}$

Pada tabel 4 tampak tidak terdapat perbedaan yang signifikan antara $\mathrm{pH}$ saliva penyirih dan yang tidak menyirih pada ketiga kelompok usia. Hasil penelitian ini sejalan dengan penelitian yang Reddy dkk, yang dikutip oleh Rooban dkk. Menurutnya, tidak terdapat perbedaan pada $\mathrm{pH}$ saliva pengunyah sirih dengan yang tidak mengunyah sirih. Penelitian yang dilakukan Rooban $\mathrm{T}$ dkk menemukan bahwa terdapat perbedaan yang signifikan antara $\mathrm{pH}$ saliva pada pengunyah sugi sirih dengan bukan penyirih. Perbedaan ini mungkin berkaitan dengan jumlah tembakau, kapur sirihnya atau komponen lainnya. ${ }^{8}$ Perbedaan yang tidak bermakna pada $\mathrm{pH}$ saliva kelompok menyirih dengan yang tidak menyirih kemungkinan karena rerata volume saliva yang dihasilkan pada kelompok menyirih dengan bukan menyirih hampir sama. Perubahan $\mathrm{pH}$ saliva juga berbanding lurus dengan volume salivanya, ${ }^{6}$ tetapi diperoleh nilai $\mathrm{p}=0,001$ yang berarti ada hubungan yang signifikan antara menyirih dengan $\mathrm{pH}$ saliva. Hal ini mungkin disebabkan penggunaan kapur sirih dalam ramuan sirih yang bereaksi dengan sistem bufer saliva sehingga mempengaruhi $\mathrm{pH}$ saliva. ${ }^{8}$ Kandungan kapur dalam ramuan sirih menyebabkan terbentuknya kalkulus lebih banyak. Kapur yang terdapat dalam ramuan sirih menaikkan $\mathrm{pH}$ saliva, sehingga bila mulut dalam keadaan basa mempercepat terbentuknya kalkulus yang berlebihan. ${ }^{2}$ Selain itu, beberapa faktor yang menyebabkan perubahan $\mathrm{pH}$ saliva, antara lain rata-rata kecepatan aliran saliva, mikroorganisme rongga mulut, dan kapasitas bufer saliva. ${ }^{5}$ Aktivitas bakteri dalam rongga mulut dapat menghasilkan asam yang menurunkan $\mathrm{pH}$ saliva. ${ }^{5}$ Anthikat dan Michael ${ }^{11}$ menemukan efek dari buah pinang yang berperan sebagai antibakteri. Mereka menemukan ekstrak pinang efektif menghambat pertumbuhan dan perkembangbiakan bakteri. Pinang diketahui menghambat pertumbuhan dan pembiakan Streptococcus mutans, bakteri yang menyebabkan karies gigi. Bagaimanapun, mengunyah tembakau bersama sirih pinang dapat menjadi agen utama penyebab kanker mulut.Pinangjuga penyebab fibrosis submukosa, yang mungkin terkait dengan penurunan metabolisme kolagen. ${ }^{11}$

Pada tabel 5 terlihat perbandingan kandungan komponen anorganik saliva rata-rata pada penyirih dengan yang tidak menyirih. Nilai $p$ yang diperoleh dari perbandingan komponen $\mathrm{Na}^{+}(\mathrm{p}=0,112)$ dan $\mathrm{K}^{+}$ $(\mathrm{p}=0,429)$ berarti tidak ada perbedaan yang signifikan antara kandungan komponen $\mathrm{Na}^{+}$dan $\mathrm{K}^{+}$saliva antara penyirih dengan bukan menyirih. Sedangkan nilai $\mathrm{p}$ yang diperoleh dari perbandingan komponen $\mathrm{Mg}^{2+}(\mathrm{p}=0,002), \mathrm{Ca}^{2+}(\mathrm{p}=0,000), \operatorname{dan}$ fosfat $(\mathrm{p}=0,001)$ ketiganya memiliki nilai $\mathrm{p}<0,05$ yang berarti ada beda yang signifikan antara kandungan komponen $\mathrm{Mg}^{2+}, \mathrm{Ca}^{2+}$, dan fosfat saliva antara penyirih dengan bukan penyirih. Perbedaan kandungan komponen anorganik saliva mungkin dipengaruhi oleh bahanbahan yang digunakan dalam aktivitas menyirih, misalnya penggunaan kapur sirih yang mungkin menyebabkan kandungan kalsium dalam saliva penyirih lebih banyak dibandingkan dengan bukan penyirih. Tembakau mengandung garam sulfat, nitrat, klorida, fosfat dan malat dari potasium kalsium dan amonium,albumin,resin,gutanin,asam sitrat, nikotin dan nikotianis. ${ }^{12}$ Kandungan bahan yang digunakan pada aktivitas menyirih kemungkinan memberikan efek pada kandungan komponen anorganik saliva. Terdapat sumber yang menyatakan bahwa kandungan elektrolit-elektrolitsalivajuga dapat dipengaruhi oleh hormon estrogen. Penelitian yang dilakukan oleh Alagendran $\mathrm{dkk}^{13}$ menunjukkan bahwa elektrolit dari 
saliva sangat tergantung pada status reproduksi wanita. Peningkatan secara perlahan pada $\mathrm{Na}^{+}$saliva terlihat pada fase ovulasi kemudian fase preovulasi dibandingkan fase pascaovulasi. Ion $\mathrm{Mg}^{2+}$ dan $\mathrm{Ca}^{2+}$ secara perlahan berkurang dari fase preovulasi ke fase ovulasi dan fase pascaovulasi ke fase ovulasi. Tingkat ion $\mathrm{Mg}^{2+}$ terendah pada fase pascaovulasi dibandingkan fase yang lain. Demikian pula dengan tingkat fosfat anorganik juga bervariasi selama siklus menstruasi. ${ }^{13}$

Disimpulkan bahwa volume, $\mathrm{pH}$, kandungan komponen $\mathrm{Na}^{+}$dan $\mathrm{K}^{+}$saliva penyirih relatif tidak berbeda dengan bukan penyirih, tetapi kandungan $\mathrm{Mg}^{2+}, \mathrm{Ca}^{2+}$ dan fosfat berbeda secara signifikan.

\section{DAFTAR PUSTAKA}

1. Hasibuan S. Karakteristik penyirih di Kabupaten Tanah Karo Sumatera Utara. Majalah Ilmiah Kedokteran Gigi. 2005; 20(60):53-8.

2. Rasmidar S, Jeni SLA. Kebiasaan mengunyah sirih, mengonsumsi tuak dan merokok pada suku Toraja di Sulawesi Selatan dan Hubungannya dengan kualitas hidup. Dentika Dent J 2009;14(2):212-7.

3. Kidd EAM, Joyston S-Bechal. Dasar-dasar karies (penyakit dan penanggulangannya). Alih bahasa: Sumawita N, Faruk S. Jakarta: EGC; 1991. p.66.

4. Ilyas M, Yusri M. Perbedaan kadar kalsium dalam saliva sebelum dan sesudah mengkonsumsi minuman ringan yang mengandung asam bikarbonat. J Dentofasial 2007;6(2):111-5.

5. Soesilo D, Santoso RE, Diyatri I. Peranan sorbitol dalam mempertahankan kestabilan $\mathrm{pH}$ saliva pada proses pencegahan karies. Majalah Kedokteran Gigi 2005;38(1):25-8.

6. Anwar DA, Supartinah Al, Handajani S. Efek kumur ekstrak teh hijau (Camellia sinensis) terhadap derajat keasaman dan volume saliva penderita gingivitis. Indonesian J Dent 2007;14(1):22-6.

7. Navazesh M, Kumar SKS. Measuring salivary flow challenges and oppoturnities. J Am Dent Assoc [serial on the internet] 2008 [cited 2010 Oct 10]; 139(2):35S-40S. Available from: http://jada.info/content/139/suppl_2/35S.full

8. Rooban T. Effect of habitual chewing on resting whole mouth salivary flow rate and $\mathrm{pH}$. Indian J Med Sci [serial on the internet] 2006 [cited 2010 Oct 10]; 60(3):95-105. Available from: http://www.bioline.org.br/request? $\mathrm{ms} 06015$

9. Sari DM. Perbedaan sekresi saliva antara mengunyah makanan asam dengan mengunyah makanan manis. J Persatuan Dokter Gigi Indonesia 2006;56(3):114-9.

10. Probosari N, Pradopo S. Peran pengunyahan terhadap perubahan volume dan ph saliva pada anak dengan gigi karies. Indonesian J Dent 2006; 13(2):115-8.

11. Anthikat RRN, Michael A. Study on the Areca nut for its antimicrobial properties. J Young Pharmacists [serial on the internet] 2009 [cited 2011 Jan 22]; 1(1):42-5. Available from:http://www.jyoungpharm.in/article.asp?issn= 0975-1483; year $=2009$; volume $=1$; issue $=1$; spage $=42$; epage $=45$; aulast $=$ Nelson

12. Handayani N. Terjadinya leukoplakia akibat pemakaian tembakau. J Indonesian Dent Assoc 2007;56(1):11-4.

13. Alagendran S. Evaluation of salivary electrolytes during normal menstrual cycle with special reference to ovulation. Am J Applied Sci [serial on the internet] 2010 [cited 2011 Jan 22]; 7(8):1066-72. Available from: http://thescipub.com/abstract/10.3844/ajassp.2010.1066.1072 